\begin{tabular}{|l|l|l||}
\hline \multicolumn{2}{|c|}{ PublisherInfo } \\
\hline \hline PublisherName & $:$ & BioMed Central \\
\hline \hline PublisherLocation & $:$ & London \\
\hline \hline PublisherImprintName & $:$ & BioMed Central \\
\hline \hline
\end{tabular}

\title{
Membrane oestrogen receptor
}

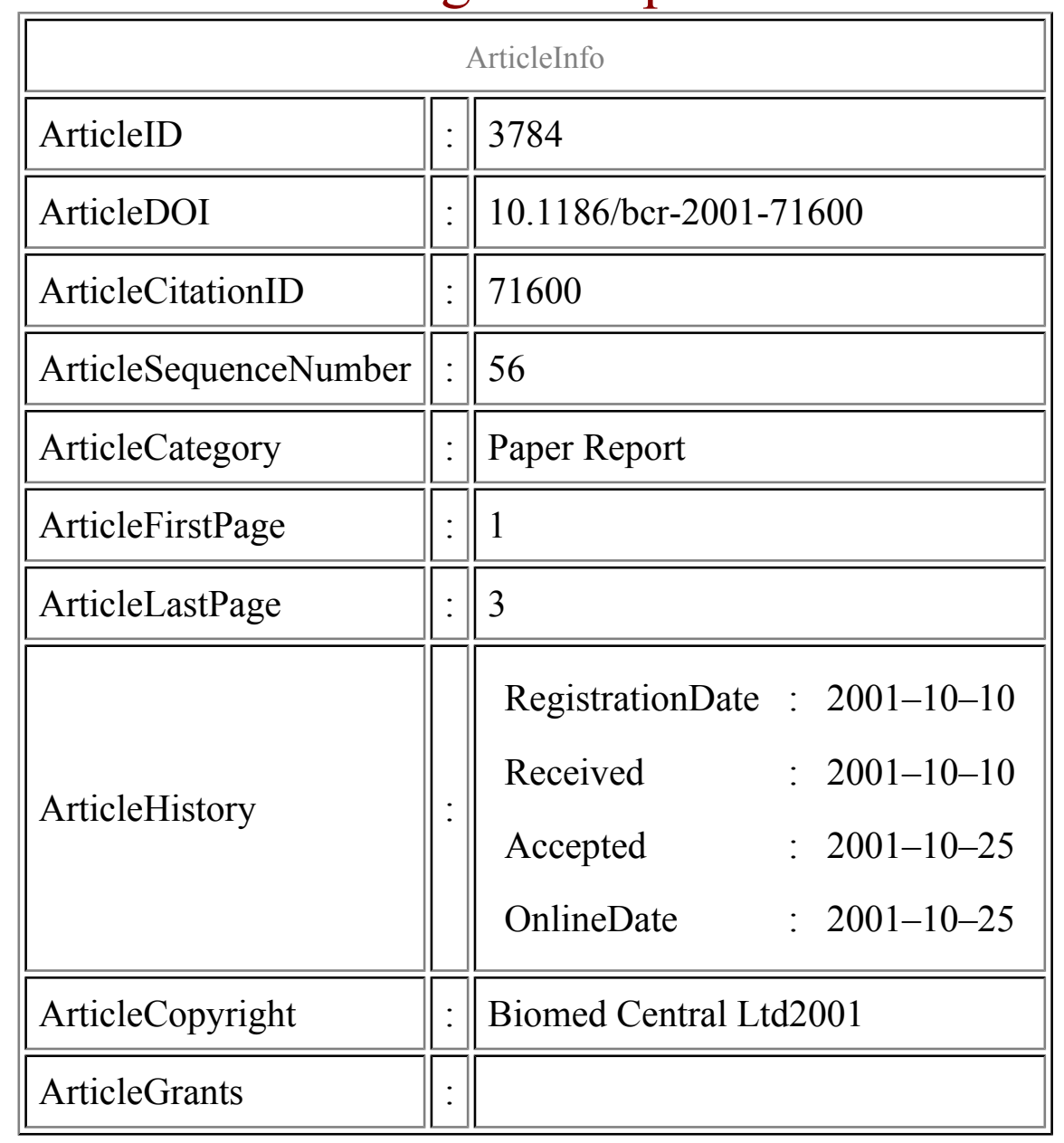




\begin{tabular}{|l|l|l|}
\hline ArticleContext & $:$ & 1305833 \\
\hline
\end{tabular}

Valerie Speirs, ${ }^{\text {Affl }}$

Aff1 Molecular Medicine Unit, University of Leeds, UK

\section{Keywords}

\section{Context}

The widely held believe that oestrogen receptor (ER) signalling is mediated via nuclear receptors is now being challenged with a resurgence of interest in a putative plasma membrane ER, first identified over 20 years ago (see Additional information). This has come about as a consequence of some of the very rapid effects of ER ligands which have been reported. The aim of this work was to identify the presence of plasma membrane ER in the human breast cancer cell line MCF-7 and to define its action.

\section{Significant findings}

Approximately $20 \%$ of specific oestradiol binding was found in the membrane fraction. This fraction was free of any contamination by cytosol or nuclei. Specific oestradiol binding sites co-purified with the plasma membrane marker 5'-nucleotidase. By western blotting using an antibody directed against ER-a but not ER-?, 4 bands were detected, a major band at $67 \mathrm{kDa}$, a secondary band at $46 \mathrm{kDa}$ and two minor bands of 62 and $97 \mathrm{kDa}$. Incubating the cells with membrane impermeable 17?-oestradiol-BSA conjugate resulted in rapid activation of mitogen activated protein kinase and Akt signalling (within 2 minutes). Additionally, oestrogen-stimulated growth of MCF-7 xenografts was significantly reduced by treatment with blocking ER antibody.

\section{Comments}

This study has illustrated the presence of a functional membrane ER in the breast cancer cell line MCF-7 which has added a further level of complexity to our understanding of ER signalling pathways. 
Although the precise function of membrane ER is currently unknown this should be the focus of future studies as it may represent a novel target for breast cancer therapy. It may also be useful in finding other, perhaps novel binding partners of ER.

\section{Methods}

Cell culture, ligand binding assay, subcellular fractionation, western blot, immunoprecipitation, transfection, xenografts

\section{Additional information}

Pietras RJ, Szego CM: Specific binding sites for oestrogen at the outer surfaces of isolated endometrial cells. Nature 1977, 265:69-72.

\section{References}

1. Marquez DC, Pietras RJ: Membrane-associated binding sites for estrogen contribute to growth regulation of human breast cancer cells. Oncogene. 2001, 20: 5420-5430. 